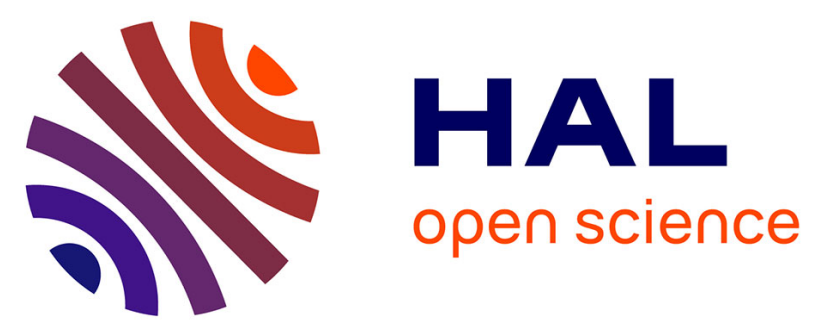

\title{
Optimization of pressurized liquid extraction using a multivariate chemometric approach and comparison of solid phase extraction cleanup steps for the determination of polycyclic aromatic hydrocarbons in mosses
}

Louise Foan, Valérie Simon

\section{To cite this version:}

Louise Foan, Valérie Simon. Optimization of pressurized liquid extraction using a multivariate chemometric approach and comparison of solid phase extraction cleanup steps for the determination of polycyclic aromatic hydrocarbons in mosses. Journal of Chromatography A, 2012, vol. 1256, pp. 22-31. 10.1016/j.chroma.2012.07.065 . hal-00917566

\author{
HAL Id: hal-00917566 \\ https://hal.science/hal-00917566
}

Submitted on 12 Dec 2013

HAL is a multi-disciplinary open access archive for the deposit and dissemination of scientific research documents, whether they are published or not. The documents may come from teaching and research institutions in France or abroad, or from public or private research centers.
L'archive ouverte pluridisciplinaire HAL, est destinée au dépôt et à la diffusion de documents scientifiques de niveau recherche, publiés ou non, émanant des établissements d'enseignement et de recherche français ou étrangers, des laboratoires publics ou privés. 


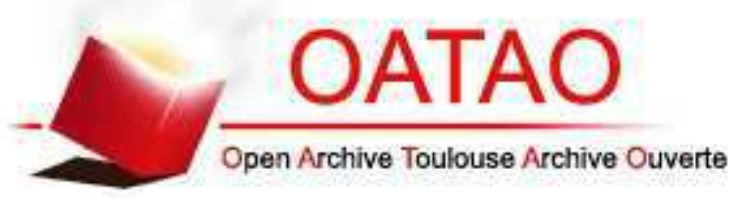

\section{Open Archive TOULOUSE Archive Ouverte (OATAO)}

OATAO is an open access repository that collects the work of Toulouse researchers and makes it freely available over the web where possible.

This is an author-deposited version published in : http://oatao.univ-toulouse.fr/ Eprints ID : 10454

To link to this article : DOI:10.1016/j.chroma.2012.07.065

URL : http://dx.doi.org/10.1016/j.chroma.2012.07.065

To cite this version : Foan, Louise and Simon, Valérie. Optimization of pressurized liquid extraction using a multivariate chemometric approach and comparison of solid phase extraction cleanup steps for the determination of polycyclic aromatic hydrocarbons in mosses. (2012) Journal of Chromatography A, vol. 1256 . pp. 22-31. ISSN 0021-9673

Any correspondance concerning this service should be sent to the repository administrator: staff-oatao@ listes-diff.inp-toulouse.fr 


\title{
Optimization of pressurized liquid extraction using a multivariate chemometric approach and comparison of solid-phase extraction cleanup steps for the determination of polycyclic aromatic hydrocarbons in mosses
}

\author{
L. Foan ${ }^{\mathrm{a}, \mathrm{b}}, \mathrm{V}$. Simon ${ }^{\mathrm{a}, \mathrm{b}, *}$ \\ a Université de Toulouse, INPT, LCA (Laboratoire de Chimie Agro-Industrielle), ENSIACET, 4 Allée Emile Monso, F-31030 Toulouse, France \\ ${ }^{\mathrm{b}}$ INRA; LCA (Laboratoire de Chimie Agro-Industrielle), F-31030 Toulouse, France
}

\begin{abstract}
A B S T R A C T
A factorial design was used to optimize the extraction of polycyclic aromatic hydrocarbons (PAHs) from mosses, plants used as biomonitors of air pollution. The analytical procedure consists of pressurized liquid extraction (PLE) followed by solid-phase extraction (SPE) cleanup, in association with analysis by high performance liquid chromatography coupled with fluorescence detection (HPLC-FLD). For method development, homogeneous samples were prepared with large quantities of the mosses Isothecium myosuroides Brid. and Hypnum cupressiforme Hedw., collected from a Spanish Nature Reserve. A factorial design was used to identify the optimal PLE operational conditions: 2 static cycles of 5 min at $80^{\circ} \mathrm{C}$. The analytical procedure performed with PLE showed similar recoveries $(\sim 70 \%)$ and total PAH concentrations $\left(\sim 200 \mathrm{ng} \mathrm{g}^{-1}\right)$ as found using Soxtec extraction, with the advantage of reducing solvent consumption by 3 ( $30 \mathrm{~mL}$ against $100 \mathrm{~mL}$ per sample), and taking a fifth of the time ( 24 samples extracted automatically in $8 \mathrm{~h}$ against 2 samples in $3.5 \mathrm{~h})$. The performance of SPE normal phases $\left(\mathrm{NH}_{2}\right.$, Florisil ${ }^{\oplus}$, silica and activated aluminium) generally used for organic matrix cleanup was also compared. Florisii ${ }^{\infty}$ appeared to be the most selective phase and ensured the highest PAH recoveries. The optimal analytical procedure was validated with a reference material and applied to moss samples from a remote Spanish site in order to determine spatial and inter-species variability.
\end{abstract}

\section{Introduction}

Polycyclic aromatic hydrocarbons (PAHs) are products of thermal decomposition, formed during incomplete combustion of organic materials and geochemical formation of fossil fuels. The main anthropogenic sources are power plants, domestic heating, waste incineration, industrial processes and, most importantly, motor vehicle exhaust emissions [1-3]. PAHs are considered to be persistent organic pollutants (POPs) due to their slow rates of degradation, toxicity and potential for both long-range transport and bioaccumulation in living organisms [4]. Carcinogenic, mutagenic and immunotoxic effects of PAHs, detrimental to human health, have frequently been reported [1,5]. Regulation of $\mathrm{PAH}$ emissions and reliable monitoring of PAH concentrations in ambient air is thus of paramount importance for public health.

\footnotetext{
* Corresponding author at: Université de Toulouse, INPT, LCA (Laboratoire de Chimie Agro-Industrielle), ENSIACET, 4 Allée Emile Monso, F-31030 Toulouse, France. Tel.: +33 534323 552; fax: +33 534323597.

E-mail address: valerie.simon@ensiacet.fr (V.Simon).
}

Atmospheric PAH levels are monitored by collecting atmospheric particles and gases with high or low volume samplers, and PAH deposition is evaluated by sampling bulk deposition and/or wet deposition in collectors $[4,6,7]$. However, the sampling devices have several drawbacks such as low sample representativeness, analytical difficulties (trace levels), cost and maintenance of equipment. Conversely, monitoring using biological samples appears to be a low cost alternative that can be easily developed globally. For this reason, plants are widely used as airborne pollution biomonitors in urban and rural environments [8]. The most common are herbaceous species [9], deciduous tree leaves [10], persistent tree leaves [11], coniferous needles [4,12], tree bark [13], lichens [14,15] and mosses $[4,15,16]$.

Bryophytes in particular have been used over the past decade as biomonitors for the assessment of airborne pollutant deposition: heavy metals [17], radionuclides [18], nitrogen [19], natural abundance of $C, N$ and $S$ isotopes [20,21] and POPs [16,22-24]. As they do not have any root system or cuticle, mosses obtain most of their nutrients from the atmosphere. Moreover, their high cationic exchange capacity and surface to volume ratio favours the accumulation of large amounts of pollutants [25]. The International Cooperative Programme on Effects of Air Pollution on 
Natural Vegetation and Crops (ICP-Vegetation), established under the United Nations Economic Commission for Europe (UNECE) Convention on Long-Range Transboundary Air Pollution (LRTAP), has monitored heavy metal deposition in Europe with mosses since 1990 [17]. A pilot study was initiated by ICP-Vegetation in 2010 to monitor POPs, particularly PAHs, at a European scale. Therefore, development of a fast and efficient analytical procedure for determining PAHs in mosses is necessary.

PAH determination in mosses is currently undertaken by solvent extraction followed by a cleanup step, associated with chromatographic analysis. Traditional extraction procedures using Soxhlet [26-28] or Soxtec apparatus $[15,29]$ do not provide enough energy to release the analytes rapidly and therefore require long extraction times (3.5-24h) and large amounts of organic solvents $(100-200 \mathrm{~mL})$. Thus, sonication extraction [25,30], microwaveassisted solvent extraction [31] and pressurized liquid extraction (PLE) [32-34], have been proposed as alternatives, with extraction taking on average $30 \mathrm{~min}$ with $20-30 \mathrm{~mL}$ of solvent. However, sonication extraction has the drawback of not being automated and, even though the microwave apparatus extracts 40 samples simultaneously, an extra filtration step is necessary to separate the matrix residues from the solvent. By comparison, PLE can perform 24 sequential extractions, with no further treatment.

With PLE - also called accelerated solvent extraction (ASE) extractions can be performed at high temperatures, since the solvents remain in a liquid state under the high pressures applied, ensuring high analyte recoveries [35]. Static extraction temperature, time and number of cycles appear to be critical experimental parameters [36-38]. Indeed, temperature has an effect on the solvent viscosity and thereby its ability to wet the matrix and solubilise the target analytes, and certain sample matrices can retain analytes within pores or other structures, thus increasing extraction time allows these compounds to diffuse into the extraction solvent. Finally, the use of static cycles was developed to introduce fresh solvent during the extraction process, which helps maintain favourable extraction equilibrium, without diluting the sample (since the flush volume is the same whatever the number of cycles). The effect of pressure is to maintain the solvents as liquids above their atmospheric boiling point, and the pressures used in PLE are well above the thresholds required to maintain the solvents in the liquid phase. Changing the pressure has very little impact on analyte recovery, so it seems unnecessary to optimize this parameter.

Several optimization procedures for PAH extraction by PLE on plant biomonitors such as mosses [34] and pine needles $[39,40]$ are available in the literature, and the univariate approach was used in these studies: one parameter was optimized while the others were set at a convenient value. However, operational parameters may interact, making it necessary to use a multivariate chemometric approach for developing the analytical method.

Selectivity is a necessary condition for obtaining reliable chromatographic results [41]. Therefore, solid-phase extraction (SPE) cleanup is usually employed to separate co-extracted matrix compounds from the target analytes as they may interfere during final determination $[40,42]$. Moreover, the isolation of target compounds from plant co-extracts, appears to be highly important when analyzing PAHs by high performance liquid chromatography coupled to fluorescence detection (HPLC-FLD) [39]. To date, no study covering comparison of SPE cleanup steps of moss extracts has been published.

In order to facilitate the use of mosses as bioindicators of organic airborne pollution, this study offers a fast, low solvent consuming and effective analytical procedure for $\mathrm{PAH}$ determination in these plants. PLE operating conditions were optimized with a factorial design and $\mathrm{PAH}$ recoveries were compared with those obtained by Soxtec extraction, whose efficiency was demonstrated in a previous study [29]. Moss extracts obtained under optimal PLE conditions were subsequently submitted to several normal phase SPE, in order to reveal the most efficient cleanup, i.e. the one offering the highest recoveries and the best selectivity. Finally, after verifying the accuracy of the optimal analytical procedure using reference material, the method was applied to moss samples from a mountainous area in Spain to determine spatial and inter-species variability on the site.

\section{Experimental}

\subsection{Materials and reagents}

\subsubsection{Moss samples}

To develop the analytical procedure, Pleurocarpous mosses Isothecium myosuroides Brid. and Hypnum cupressiforme Hedw. were collected in the Bertiz Nature Reserve (Navarra, Spain) between 2008 and 2010. The former was used for optimizing the extraction procedure and the latter for finding the most efficient cleanup. Two different species were used, because large amounts of material were needed to develop the analytical procedure, and the Nature Reserve authorities limit the quantity of mosses sampled, for conservation reasons. All analyses were performed on homogeneous material (cf. Section 2.2) prepared with composite samples. Approximately $0.5 \mathrm{~m}^{2}$ of each species was collected, giving 50 and $25 \mathrm{~g}$ (dry weight) of I. myosuroides Brid. and $H$. cupressiforme Hedw. respectively.

After validation, the optimal parameters were applied to moss samples collected in June $\mathbf{2 0 1 0}$ from a low-alpine site in the Aralar Range (Navarra, Spain). The aim of the study was to validate the use of the moss species Hylocomium splendens (Hedw.) Schimp. for monitoring atmospheric deposition of PAHs in a rural environment. Initially, spatial variability in sampling was evaluated by collecting 9 samples from the same site ( $\sim 0.02 \mathrm{~m}^{2}$ per sample), and the PAH levels were compared with those of $H$. cupressiforme Hedw., because the latter had been used in a previous study for monitoring atmospheric deposition of PAHs in Navarra [29]. To this end, samples of $H$. cupressiforme ( $\sim 0.04 \mathrm{~m}^{2}$ per sample) were taken at the same site as $H$. splendens. Mosses were collected under the surveillance of the Navarra authorities, and due to its scarcity in the Aralar Range, a maximum of only 3 samples of $H$. cupressiforme was allowed.

\subsubsection{Chemicals and standards}

A standard mix containing acenaphthene (ACE), fluorene (FLR), phenanthrene (PHE), anthracene (ANT), fluoranthene (FTN), pyrene (PYR), benz(a)anthracene (B(a)A), chrysene (CHR), benzo(b)fluoranthene $(B(b) F)$, benzo(k)fluoranthene $(B(k) F)$, benzo(a)pyrene $(B(a) P)$, dibenz $(a, h)$ anthracene $(D(a h) A)$, and benzo(ghi)perylene ( $\mathrm{B}(\mathrm{ghi}) \mathrm{P}$ ) at $10 \mu \mathrm{g} \mathrm{mL}^{-1}$ of acetonitrile, was used for calibration (Mix 16 HAP, LGC Standards, Teddington, UK). Deuterated PAHs were used as surrogate standards (anthracene $d_{10}$ and benzo(a)pyrene $d_{12}$ at $10 \mu \mathrm{g} \mathrm{mL}^{-1}$ in acetonitrile) and as internal standard (fluoranthene $d_{10}$ at $100 \mu \mathrm{g} \mathrm{mL}^{-1}$ in acetonitrile) (LGC Standards, Teddington, UK).

A reference material IAEA-140-OC (35 g) (ANALAB, Bischheim, France), consisting of a common brown seaweed (Fucus sp.) and characterized for the mass fractions of certain organic contaminants, was used to evaluate the accuracy of the analytical method. The International Atomic Energy Agency supplies reference values for organochlorine pesticides, PCB congeners, petroleum hydrocarbons and PAHs for this material, based on an international inter-laboratory comparison [43].

All solvents were HPLC grade: acetonitrile, cyclohexane, dichloromethane (DCM) and $n$-hexane were provided by Scharlau 


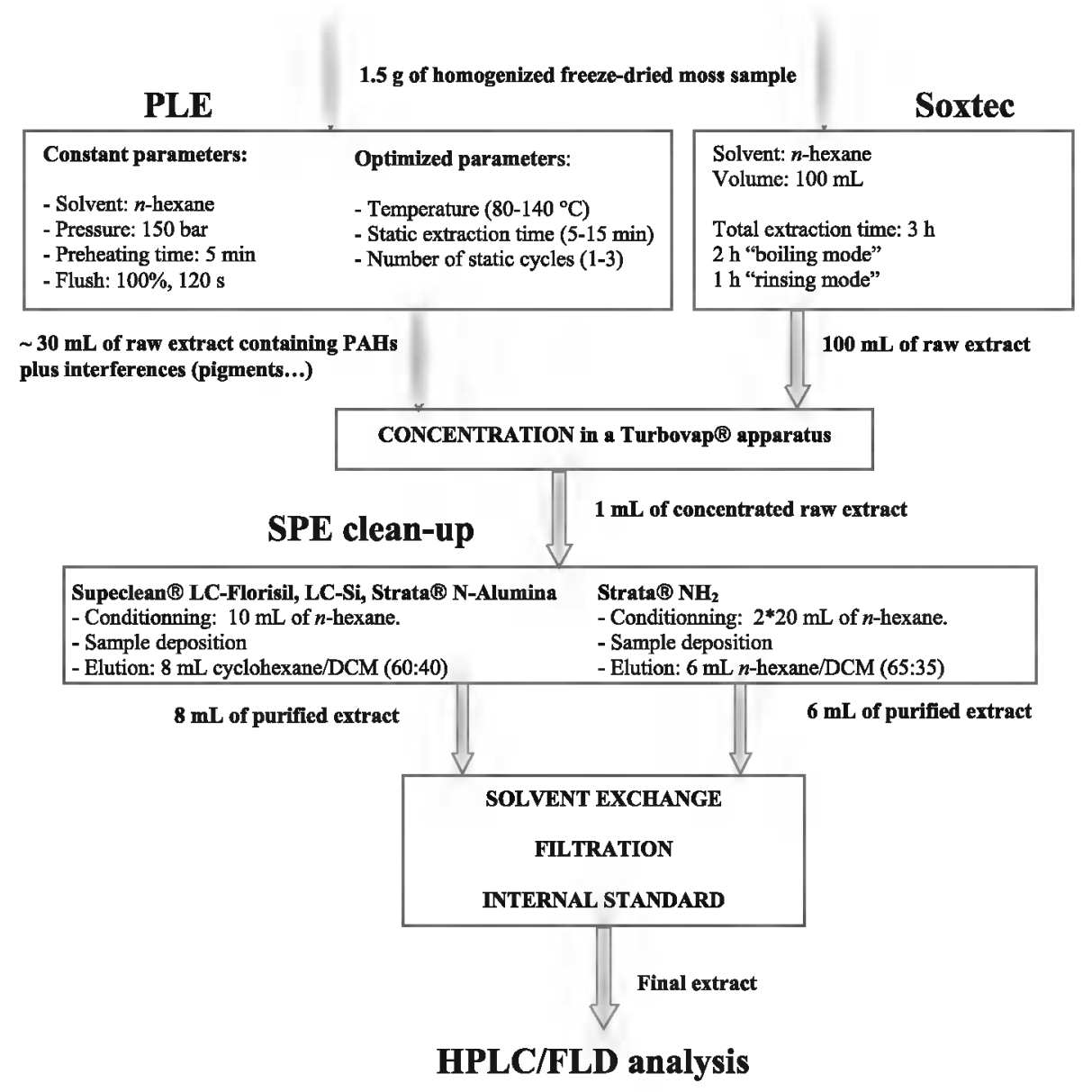

Fig. 1. Diagram illustrating all operations of the analytical procedure to optimize $P A H$ determination in mosses.

(Sentmenat, Spain) and Milli-Q water by Millipore (Billerica, MA, USA).

\subsection{Sample preparation}

Any litterfall (dead leaves, twigs. ..) attached to the moss samples was removed with stainless steel tweezers. The green and green-brown shoots from the last three years growth were withdrawn using stainless steel tweezers and scissors. Brown parts were not included in the samples, even if the remaining green parts represented less than three years of growth.

The unwashed samples were freeze-dried - recommended to minimize loss of volatile compounds during preparation $[44,45]$ with an Alpha 2-4 LD apparatus for $24 \mathrm{~h}$ (Martin Christ, Osterode am Harz, Germany). To obtain homogeneous samples, the lyophilized mosses were ground to a fine powder in a stainless steel mill (particle size $<0.5 \mathrm{~mm}$ ).

\subsection{Solvent extraction and SPE cleanup}

First, PLE was optimized and compared with previously validated Soxtec extraction [29]. Then, during a second phase, different sorbent phases were compared for the SPE cleanup. The analytical procedure is shown in Fig. 1.

\subsubsection{Pressurized liquid extraction}

PLE extractions were performed with an ASE 200 apparatus (DIONEX, Sunnyvale, CA, USA). Homogenized moss samples of $1.5 \mathrm{~g}$ were extracted in $11 \mathrm{~mL}$ stainless steel cells with $0.75 \mathrm{~g}$ of anhydrous sodium sulfate and $0.75 \mathrm{~g}$ of Florisi ${ }^{\circledR}$ (activated magnesium silicate) from U.S. Silica Company (Berkeley Springs, USA). The sorbents were layered at the outlet of the extraction cells. Anhydrous sodium sulfate was used to ensure total dryness of the cell content to avoid problems of water immiscibility with nonpolar solvents. Florisil ${ }^{\circledR}$ was used to retain co-extracted polar compounds which could interfere with PAHs during analysis. In-line selective removal of interferences avoids drastic post-extraction cleanup steps [46] Each sample was spiked with 50 ng of surrogate standards ANT $d_{10}$ and $\mathrm{B}(\mathrm{a}) \mathrm{P} \mathrm{d}_{12}$, chosen to estimate the recoveries of the light $\mathrm{PAH}$ fraction (ACE to PYR) and heavy PAH fraction (B(a)A to $B($ ghi)P), respectively.

Extractions were carried out with $n$-hexane at a pressure of 150 bar. The cells were preheated for $5 \mathrm{~min}$ to reach thermal equilibrium, then were submitted to one or several static extraction cycles. After each cycle, the cells were flushed with a volume of fresh solvent corresponding to $100 \%$ of the cell volume divided by the number of cycles. Finally, at the end of the extraction process, the cells were purged with purified nitrogen for $120 \mathrm{~s}$. The solvent and fixed operational parameters were chosen in the light of a previous study [34] that demonstrated their efficiency for PLE extraction of PAHs from mosses.

Nonpolar/polar solvent mixtures such as DCM/acetone or $n$ hexane/acetone have shown high PAH recoveries in previous PLE studies performed on environmental samples $[39,47]$. However, high co-extraction of matrix polar compounds such as pigments and lipids was also observed. Hence, with polar solvents, a more drastic cleanup procedure is necessary to ensure interference free chromatographic analysis. Thus the choice of a non-polar solvent, such as $n$-hexane, for PLE extraction seems preferable to obtain lighter extracts containing low matrix residue content. This solvent 
Table 1

Central factorial design used for the PLE optimization of PAH extraction from mosses.

\begin{tabular}{lccl}
\hline Experiment no. & $\begin{array}{l}\text { Temperature, } \\
T\left({ }^{\circ} \mathrm{C}\right)\end{array}$ & $\begin{array}{l}\text { Static time, } \\
\boldsymbol{t}_{\mathbf{s}}(\mathrm{min})\end{array}$ & $\begin{array}{l}\text { Number of } \\
\text { cycles, } \boldsymbol{N}\end{array}$ \\
\hline 1 & 80 & 5 & 1 \\
2 & 80 & 5 & 3 \\
3 & 80 & 15 & 3 \\
4 & 80 & 15 & 1 \\
5 & 140 & 5 & 1 \\
6 & 140 & 5 & 3 \\
7 & 140 & 15 & 1 \\
8 & 140 & 15 & 3 \\
9 & 80 & 5 & 1 \\
10 & 80 & 5 & 3 \\
11 & 80 & 15 & 3 \\
12 & 80 & 15 & 1 \\
13 & 140 & 5 & 1 \\
14 & 140 & 5 & 3 \\
15 & 140 & 15 & 1 \\
16 & 140 & 15 & 3 \\
17 & 110 & 10 & 2 \\
18 & 110 & 10 & \\
\hline
\end{tabular}

also has the advantage of being highly volatile, ensuring a fast concentration step, and is compatible with the normal cleanup phases.

The PLE experimental design was developed to identify the optimal values of static extraction temperature, static time and number of static cycles. Several studies concerning PLE applied to bioindicators for PAH determination use operating temperatures from 80 to $140^{\circ} \mathrm{C}$, static extraction times of $5-15 \mathrm{~min}$ and a maximum of 3 cycles $[33,34,39]$. These limits were assigned to each variable for the experimental design (Table 1).

Before SPE cleanup, the extracts were concentrated to $1 \mathrm{~mL}$ with purified $\mathrm{N}_{2}$ (Alpha 1, Air Liquide, Paris, France) in a Turbovap II apparatus (Caliper Life Sciences, Hopkinton, MA, USA).

\subsubsection{Soxtec extraction}

The extractions were performed with a Soxtec System HT2 (Tecator, France). $1.5 \mathrm{~g}$ moss samples spiked with $50 \mathrm{ng}$ of surrogate standards were extracted in cellulose thimbles with $0.75 \mathrm{~g}$ of anhydrous sodium sulfate and $0.75 \mathrm{~g}$ of Florisi ${ }^{\circledR}$ (U.S. Silica Company, Berkeley Springs, USA).

Extractions were carried out with $100 \mathrm{~mL}$ of $n$-hexane. The thimbles were first immersed in the boiling solvent for $2 \mathrm{~h}$ and then raised above the solvent to be rinsed for $1 \mathrm{~h}$ by the condensing solvent.

Before SPE cleanup, the extracts were concentrated to $1 \mathrm{~mL}$ with purified $\mathrm{N}_{2}$ (Alpha 1, Air Liquide, Paris, France) in a Turbovap II apparatus (Caliper Life Sciences, Hopkinton, MA, USA).

\subsubsection{SPE cleanup procedure}

During the PLE optimization and validation, cleanup was performed with Florisil ${ }^{\circledR}$ SPE cartridges (Supelclean LC-Florisil SPE $1 \mathrm{~g} / 6 \mathrm{~mL}$ from Supelco Analytical, Sigma-Aldrich, St. Louis, MO, USA). The use of these cartridges and their elution protocol has been validated previously [29].

During the second stage of the study, cleanup using several normal phase SPE cartridges was tested: Supelclean LC-Florisil SPE $1 \mathrm{~g} / 6 \mathrm{~mL}$ and Supelclean LC-Si SPE $1 \mathrm{~g} / 6 \mathrm{~mL}$ from Supelco Analytical (Sigma-Aldrich, St. Louis, MO, USA); Strata $\mathrm{NH}_{2} 1 \mathrm{~g} / 6 \mathrm{~mL}$ and Strata Alumina-N $120 \mu \mathrm{m}, 120 \AA, 1 \mathrm{~g} / 6 \mathrm{~mL}$ from Phenomenex (Le Pecq, France). Cartridges of the same volume were chosen, with equal sorbent mass.

The SPE was performed using a Supelco manifold (Sigma-Aldrich, St. Louis, MO, USA). The LC-Florisil, LC-Si and $\mathrm{N}$-Alumina cartridges were conditioned with $10 \mathrm{~mL}$ of $n$-hexane, the $\mathrm{NH}_{2}$ cartridges with $2 \times 20 \mathrm{~mL}$ of $n$-hexane. After sample deposition, PAH elution was performed with $8 \mathrm{~mL}$ of cyclohexane/DCM
$(60: 40, v / v)$ for the first three cartridges containing polar adsorption media and with $6 \mathrm{~mL}$ of $n$-hexane/DCM $(65: 35, \mathrm{v} / \mathrm{v})$ for the $\mathrm{NH}_{2}$ bonded cartridges. The elution protocols were based on previous studies of SPE cleanups on pine needles, lichens and moss extracts for PAH analysis $[29,40,48]$, which systematically used a mixture of nonpolar solvent, $n$-hexane or cyclohexane, and a slightly polar solvent, dichloromethane. The polarity of these mixtures ensures efficient $\mathrm{PAH}$ elution, as polar co-extracted matrix compounds stay adsorbed on the normal phase sorbents. For example, Blasco et al. carried out lichen extract cleanup with $\mathrm{NH}_{2}$ bonded cartridges and measured $95 \%$ of PAH recovery and $98 \%$ of matrix compounds elimination with $n$-hexane/DCM elution [48].

The extracts were concentrated to $0.1 \mathrm{~mL}$ under a gentle stream of nitrogen (Alpha 1, Air Liquide, Paris, France), then $1 \mathrm{~mL}$ of acetonitrile was added. Finally, extracts were filtered with PTFE syringe filters (I.D. $13 \mathrm{~mm}, 45 \mu \mathrm{m}$ ) (Xilab, Atlanticlabo-ICS, Bruges, France), and $80 \mathrm{ng}$ of internal standard FTN $\mathrm{d}_{10}$ was added. The extracts were stored at $-20^{\circ} \mathrm{C}$.

\subsection{HPLC-FLD analysis}

The PAH analyses were performed with a high-performance liquid chromatography system consisting of a P680 HPLC pump and an RF 2000 fluorescence detector (Dionex, Sunnyvale, CA, USA). An 8125 low dispersion injector (Rheodyne, Rohnert Park, CA, USA) was fitted with a $20 \mu \mathrm{L}$ loop. The system was equipped with a $250 \mathrm{~mm} \times 4.6 \mathrm{~mm}$ I.D. Supelcosil ${ }^{\mathrm{TM}}$ LC-PAH C18 column (particle size $5 \mu \mathrm{m}$ ) and a $20 \mathrm{~mm} \times 4.6 \mathrm{~mm}$ I.D. precolumn (particle size $5 \mu \mathrm{m}$ ) (Supelco Analytical, Sigma-Aldrich, St. Louis, MO, USA). Their temperatures were controlled with an Ultimate 3000 column compartment (Dionex, Sunnyvale, CA, USA). Chromeleon 6.80 Chromatography Data System (SR10 Build 2818(166959)) was used for data acquisition (Dionex, Sunnyvale, CA, USA).

Elution was carried out with a binary solvent gradient of water and acetonitrile (ACN) at a flow rate of $1.5 \mathrm{~mL} \mathrm{~min}^{-1}$. The gradient elution program was as follows: initial conditions with $60 \% \mathrm{ACN}$ maintained for $5 \mathrm{~min}$, followed by a $25 \mathrm{~min}$ linear ramp to $100 \%$ $\mathrm{ACN}$ and finally a 10 min plateau at $100 \% \mathrm{ACN}$. The column temperature was set at $30^{\circ} \mathrm{C}$. Detection was performed with selected fluorescence wavelengths to obtain the best sensitivity and minimal interference. The excitation/emission wavelength pairs (nm) are given in Table 2.

\subsection{Quality assurance (QA) and quality control (QC)}

Detection (LOD) and quantification (LOQ) limits were determined by studying the chromatogram obtained with a $2 \mathrm{ng} \mathrm{mL}^{-1}$ standard solution. The LOD was calculated as equal to three times the background $(\mathrm{S} / \mathrm{N}=3)$ and the $\mathrm{LOQ}$ as 10 times the background $(S / N=10)[49]$. Quantification limits are given in Table 2.

Calibration curves were prepared for six levels $(0,2,5,10$, $50,150 \mathrm{ng} \mathrm{mL}^{-1}$ ) and each calibration level was injected in triplicate. The linearity range for the PAH analysis extended from LOQ to $150 \mathrm{ng} \mathrm{mL}^{-1}$ with regression coefficients from 0.9993 (FLR) to 0.9999 (PHE, ANT, FTN, B(a)A, CHR, B(b)F, B(k)F, D(ah)A).

Repeatability was satisfactory since the uncertainty (as defined in (1) [50]) of 10 replicate analyses of the $2 \mathrm{ng} \mathrm{mL}^{-1}$ standard solution ranged from 1 to $10 \%$.

Uncertainty $=\frac{t \times \mathrm{SD}}{\sqrt{n}}$

where $t$ is the Student's $t$-value, SD is the standard deviation, and $n$ is the number of injections.

The optimal analytical procedure showed average surrogate recoveries of $70 \%$ for $A N T d_{10}$ and $68 \% B(a) P d_{12}$. Reproducibility $(n=6)$ ranged from 1 to $22 \%$ (for PYR and ANT respectively) (cf. 
Table 2

Analytical parameters for PAH analysis by HPLC-FLD. Excitation (Exc. $\lambda$ ) and emission (Em. $\lambda$ ) wavelengths were chosen as a function of the compounds analyzed. The limits of quantification (LOO) are expressed in mass of injected compound (pg). As a rough guide, equivalent concentrations in mosses (ng $\mathrm{g}^{-1} \mathrm{dry}$ weight) have been calculated (for $1.5 \mathrm{~g}$ of moss sample treated, and with satisfactory PAH recoveries of 70\%).

\begin{tabular}{|c|c|c|c|c|c|c|c|}
\hline Time window & Time (min) & Exc. $\lambda(\mathrm{nm})$ & $\operatorname{Em} . \lambda(\mathrm{nm})$ & Compounds & Retention time (min) & LOQ (pg) & $\begin{array}{l}\text { Equivalent LOQ in } \\
\left.\text { mosses (ng } g^{-1} \mathrm{DW}\right)\end{array}$ \\
\hline \multirow[b]{2}{*}{1} & \multirow{2}{*}{8.0} & \multirow{2}{*}{233} & \multirow{2}{*}{320} & ACE & 9.2 & 22 & 1.0 \\
\hline & & & & FLR & 9.7 & 52 & 2.5 \\
\hline 2 & 10.5 & 260 & 380 & PHE & 11.4 & 27 & 1.3 \\
\hline \multirow{2}{*}{3} & \multirow{2}{*}{12.0} & \multirow{2}{*}{250} & \multirow{2}{*}{375} & ANT- $d_{10}$ & 12.5 & & \\
\hline & & & & ANT & 13.1 & 4 & 0.2 \\
\hline \multirow[b]{2}{*}{4} & \multirow{2}{*}{13.8} & \multirow{2}{*}{365} & \multirow{2}{*}{462} & FTN-d 10 & 14.3 & & \\
\hline & & & & FTN & 14.9 & 28 & 1.3 \\
\hline 5 & 15.6 & 275 & 380 & PYR & 16.4 & 13 & 0.6 \\
\hline \multirow{4}{*}{6} & \multirow{4}{*}{18.0} & \multirow{4}{*}{270} & \multirow{4}{*}{300} & $B(a) A$ & 21.3 & 15 & 0.7 \\
\hline & & & & CHR & 22.5 & 16 & 0.8 \\
\hline & & & & $B(b) F$ & 26.5 & 6 & 0.3 \\
\hline & & & & $\mathrm{B}(\mathbf{k}) \mathrm{F}$ & 28.4 & 3 & 0.1 \\
\hline \multirow[t]{3}{*}{7} & \multirow[t]{3}{*}{22.1} & \multirow[t]{3}{*}{302} & \multirow[t]{3}{*}{431} & $\mathrm{~B}(\mathrm{a}) \mathrm{P}-\mathrm{d}_{12}$ & 29.0 & & \\
\hline & & & & $\mathrm{B}(\mathrm{a}) \mathrm{P}$ & 30.0 & 12 & 0.6 \\
\hline & & & & $D(a h) A$ & 32.3 & 7 & 0.3 \\
\hline 8 & 33.4 & 302 & 419 & B(ghi)P & 33.9 & 6 & 0.3 \\
\hline
\end{tabular}

Section 3.1). The accuracy was also verified with the reference material (cf. Section 3.4).

\subsection{Experimental design approach}

To understand the way in which PLE operating variables affect $\mathrm{PAH}$ extraction, individual operating variables must be considered along with interaction terms. The operating variables, temperature $(T)$, static extraction time $\left(t_{s}\right)$ and number of $\operatorname{cycles}(N)$, were studied using a factorial design (Nemrodw, LPRAI, Marseille, France). Each of the variables was set at 3 coded levels: $-1,0$ and +1 , requiring 18 experiments in total (Table 1 ).

The results from the factorial design can be assessed using multilinear regression (Nemrodw, LPRAI, Marseille, France), with an equation of the form:

$Y=b_{0}+b_{1} T+b_{2} t_{s}+b_{3} N+b_{12} T t_{s}+b_{13} T N+b_{23} t_{s} N$

where $Y$ is the extraction recovery and $b_{0}$ the intercept. This first degree model was validated using a Fischer test. Each regression coefficient was tested using a Student's $t$ test with a corresponding $p$-value. The factors whose $p$-values were less than 0.05 were considered as, "statistically significant".

\section{Results and discussion}

\subsection{Optimization of the PLE method}

The factorial design revealed recoveries of $56-75 \%$ for ANT $d_{10}$ (surrogate for ACE to PYR) and from 58 to $71 \%$ for $B(a) P d_{10}$ (surrogate for $B(a) A$ to $B($ ghi)P) (Fig. 2), in agreement with the results obtained in the literature with $n$-hexane over the same extraction temperature ranges, static extraction time and number of cycles [33,34].

Variance analysis of the factorial design with a Fischer test validated the choice of a first degree model. Indeed, a variance coefficient of $F=2$, strictly inferior to the Fischer coefficient $F_{\text {Fischer }}=6$, showed that the variability of the central point was significantly lower than the variability over the factorial design.

Multilinear regression was applied to the light and heavy PAH recoveries obtained with the central factorial design. Statistical treatment of the results is shown in Table 3. At the 95\% confidence level ( $p$-value $<0.05$ ), the PLE operational parameters studied in the factorial design had an insignificant effect on light and heavy $\mathrm{PAH}$ recoveries, except for extraction temperature which had a significant effect on heavy PAH recoveries (99\% confidence level, $p$-value <0.01). This parameter is therefore the key to PLE optimization. The interaction between the terms corresponding to the extraction temperature and the number of static cycles was particularly important as it appeared to have a significant effect on heavy PAH recoveries at the $95 \%$ confidence level $(p$-value $<0.05)$. The response surface representing heavy PAH fraction recoveries showed that optimal conditions were reached with a minimum temperature of $80^{\circ} \mathrm{C}$ and a maximal extraction time of $45 \mathrm{~min}$ ( 3 cycles of $15 \mathrm{~min}$ ) (Fig. 3). However, at the optimal temperature of

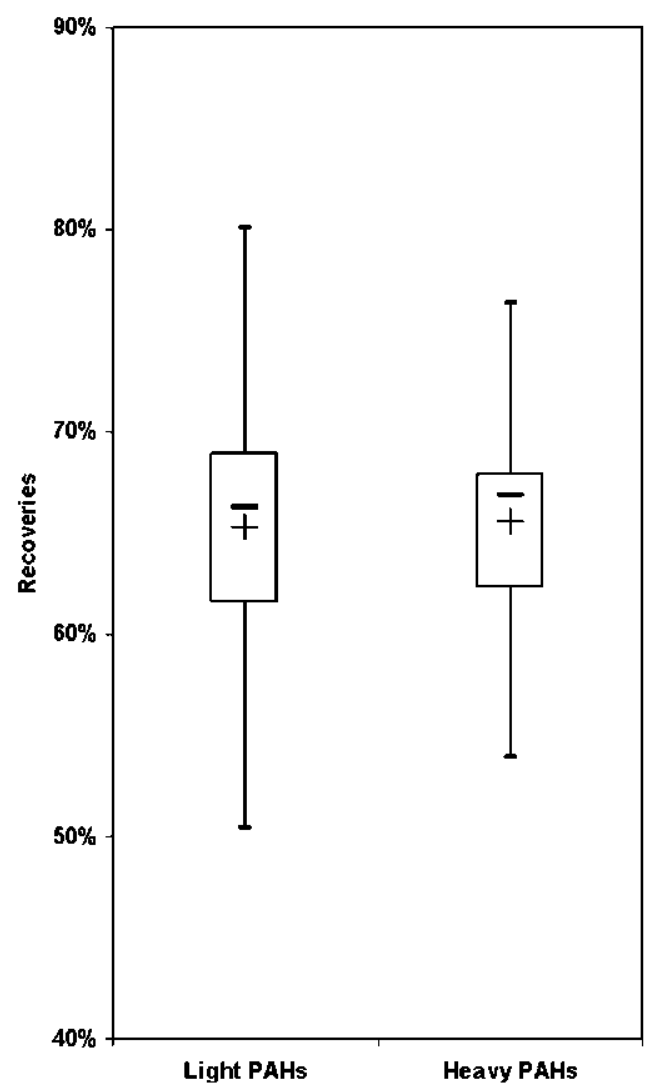

Fig. 2. Box-plots of the recoveries obtained with the PLE factorial design (1-3 static extraction cycles of $5-15 \mathrm{~min}$ at $80-140^{\circ} \mathrm{C}$ ) for light PAHs (ACE $\rightarrow$ PYR) and heav PAHs (B(a)A $\rightarrow B$ (ghi)P). The box boundaries indicate the 25 th and 75 th percentiles. The horizontal lines and plus signs $(+)$ within the boxes represent the median and mean values respectively. 
Table 3

Multilinear regression coefficients of the first order models of light and heavy PAH recoveries associated with the p-values obtained by Student's $t$ test and their degree of "statistical significance".

\begin{tabular}{|c|c|c|c|c|c|c|c|}
\hline \multirow[t]{2}{*}{ Parameter } & \multirow[t]{2}{*}{ Variable } & \multicolumn{3}{|c|}{ Light PAH recoveries } & \multicolumn{3}{|c|}{ Heavy PAH recoveries } \\
\hline & & Coefficient & $p$ value & Significance & Coefficient & $p$ value & Significance \\
\hline$b_{0}$ & & 0.6525 & $<0.0001$ & $m$ & 0.6600 & $<0.0001$ & $m$ \\
\hline$b_{1}$ & $T$ & -0.0022 & 0.8900 & - & -0.0281 & 0.0038 & $*$ \\
\hline$b_{2}$ & $t_{s}$ & -0.0041 & 0.7990 & - & 0.0128 & 0.0840 & - \\
\hline$b_{3}$ & $\boldsymbol{N}$ & -0.0194 & 0.2540 & - & -0.0020 & 0.7550 & - \\
\hline$b_{12}$ & T.ts & -0.0074 & 0.6480 & - & 0.0089 & 0.2000 & - \\
\hline$b_{13}$ & $T . N$ & 0.0014 & 0.9310 & - & -0.0206 & 0.0155 & - \\
\hline$b_{23}$ & $t_{s} N$ & -0.0286 & 0.1030 & - & -0.0008 & 0.8990 & - \\
\hline
\end{tabular}

$p<0.05$

$* 0.01$.

- $p<0.001$.

$80^{\circ} \mathrm{C}$, average recoveries varied insignificantly with total extraction time.

The extracts obtained with $n$-hexane were pale yellow, green or brown, depending on the operational parameters (Fig. 4). At $80^{\circ} \mathrm{C}$ (1-4), the colour of the extracts was less intense than at $140^{\circ} \mathrm{C}$ (5-8), as low temperatures induced less co-extraction of matrix compounds, as shown previously by Jánská et al. [39]. Moreover, with $80^{\circ} \mathrm{C}$ static extraction temperatures, extracts were darker when the PLE was operated with 1 cycle (experiments 1 and 4) than with 3 cycles (experiments 2 and 3 ). Carrying out several cycles ensures better in-cell cleanup by Florisil ${ }^{\circ}$, as less extract passes through the sorbent during each flush. As low interference is necessary during HPLC-FLD analysis, extractions should therefore be performed at $80^{\circ} \mathrm{C}$ with at least two static cycles. To develop the shortest analytical procedure possible, and since total extraction time had barely any influence on PAH recoveries, the optimal extraction appeared to be with 2 cycles of $5 \mathrm{~min}$.

After studying the quantitative and qualitative aspects of the PLE method, the optimal parameters chosen were:

- Extraction temperature: $80^{\circ} \mathrm{C}$.

- Static extraction time: $5 \mathrm{~min}$.

- Number of cycles: 2

These conditions were similar to those found in the literature concerning the optimization of PAH extraction by PLE in

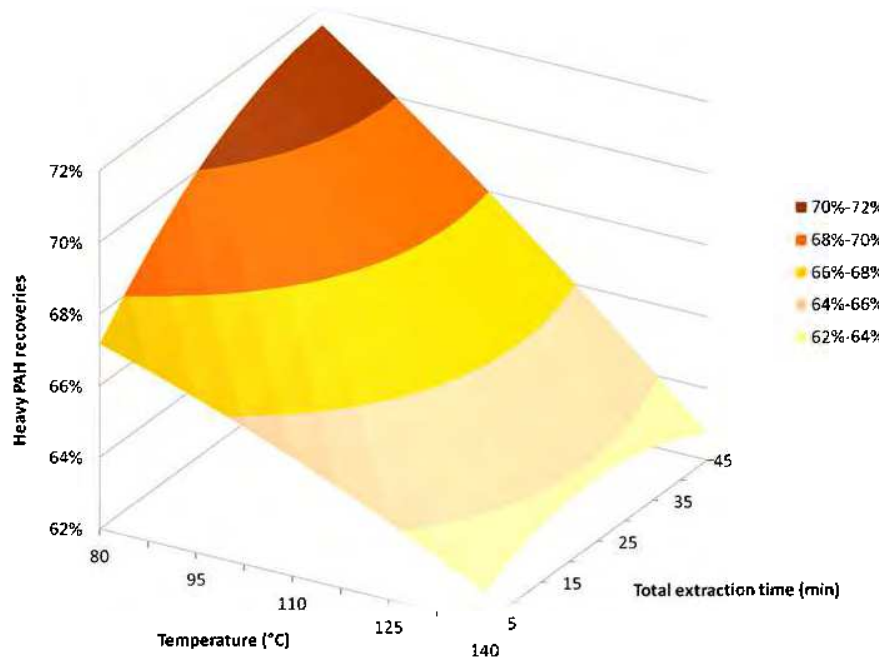

Fig 3. Response surface of the factorial design representing recoveries of the heavy $\mathrm{PAH}$ fraction (B(a)A $\rightarrow \mathrm{B}($ ghi)P), obtained by plotting extraction temperature against total extraction time. environmental samples such as soil, sediments and particulate matter: generally $1-2$ cycles of $5 \mathrm{~min}$ at $100^{\circ} \mathrm{C}[36,38]$.

The optimal conditions were tested using 6 repetitions of the analytical procedure. The extracts obtained were bright yellow and did not contain any visible matrix residues. Moreover, the extracts showed average recoveries of $70 \%$ and $68 \%$ for light and heavy PAHs respectively. These results were satisfactory as they tallied with the highest quartiles of light and heavy PAH recoveries obtained with the factorial design (shown in Fig. 2). Average total PAH concentrations of $233 \pm 6 \mathrm{ngg}^{-1}$ were measured for 13 PAHs in $I$. myosuroides Brid. (Table 4). FLR, PHE, FTN and PYR appeared as the major compounds. These levels were within the ranges of concentrations measured in 2006-2007 in four other pleurocarpous moss species sampled from the same site [29]. These results also validate the reproducibility of the method as the relative standard deviation of the total concentrations was $2 \%$ and of the individual concentrations of 1-22\% (for PYR and ANT respectively).

\subsection{Comparison with Soxtec extraction}

Soxtec extraction provided similar yellow extracts to those obtained with optimal PLE, as well as equivalent surrogate recoveries: 77\% for light PAHs (ACE to PYR) and 67\% for heavy PAHs (B(a)A to $\mathrm{B}(\mathrm{ghi}) \mathrm{P})$. Moreover, the individual $\mathrm{PAH}$ concentrations measured after PLE and Soxtec extraction were within the same range, except for ACE and FLR (Table 4). During analysis, these two-ring aromatic compounds sometimes interfered with matrix compounds, leading to difficult quantification, and as they are volatile, losses may have occurred during Soxtec extraction. These observations confirm the necessity for evaluating the accuracy of the PLE method

Table 4

Mean PAH concentrations (ng $\mathrm{g}^{-1}$ dry weight) and corresponding standard deviations (SD) measured in Isothecium myorusoides Brid. by HPLC-FLD after extraction with the optimal PLE conditions $(n=6)$ and comparison with the levels measured after Soxtec extraction $(n=3)$.

\begin{tabular}{lrrrrr}
\hline PAHs & \multicolumn{2}{l}{ Optimal PLE $(n-6)$} & & \multicolumn{2}{c}{ Soxtec $(n-3)$} \\
\cline { 2 - 3 } \cline { 5 - 6 } & Mean & SD & & Mean & SD \\
\hline ACE & 2.0 & 0.1 & 2.6 & 0.2 \\
FLR & 35.6 & 3.3 & 14.0 & 2.2 \\
PHE & 29.4 & 3.1 & 29.6 & 3.7 \\
ANT & 1.8 & 0.4 & 1.7 & 0.2 \\
FTN & 43.4 & 1.8 & 42.0 & 6.8 \\
PYR & 96.7 & 1.3 & 100.5 & 18.1 \\
B(a)A & 3.4 & 0.6 & 4.2 & 0.4 \\
CHR & 9.5 & 1.1 & 11.0 & 1.3 \\
B(b)F & 2.3 & 0.2 & 2.4 & 0.1 \\
B(k)F & 2.2 & 0.4 & 2.1 & 0.1 \\
B(a)P & 4.1 & 0.5 & 4.1 & 0.2 \\
D(ah)A & 0.7 & 0.1 & 0.9 & 0.1 \\
B(ghi)P & 5.4 & 0.5 & 5.3 & 0.3 \\
Total & 233.5 & 5.5 & 220.3 & 31.1 \\
\hline
\end{tabular}




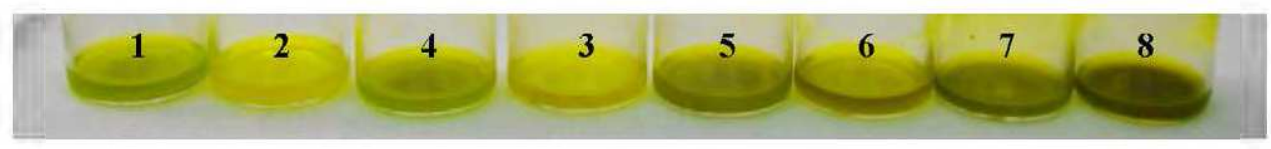

Fig. 4. Concentrated extracts obtained from experiments 1-8 of the factorial design. See Table 1 for details.

with a reference material. Average total concentrations measured with the two methods showed a low relative difference of $6 \%$. Soxtec ensured 2 parallel extractions with $200 \mathrm{~mL}$ of solvent in $3.5 \mathrm{~h}$ ( $\sim 0.6$ extractions per hour), whereas optimal PLE conditions (2 static cycles of $5 \mathrm{~min}$ ) led to 3 extractions per hour with $30 \mathrm{~mL}$ of solvent per sample. Therefore, optimal PLE conditions were as efficient as Soxtec for PAH extraction from mosses, with the advantage of being five times faster and of consuming three times less solvent.

\subsection{Cleanup procedure}

Strata $\mathrm{NH}_{2}$ cartridges were immediately eliminated during preliminary tests because quantification with HPLC/FLD analysis was impossible due to the presence of high quantities of interfering compounds on the chromatograms. Conversely, analysis of the purified extracts obtained with Strata Alumina-N, Supelclean LC-Florisil and Supelclean LC-Si SPE cartridges was possible. Recoveries of light and heavy PAHs were determined for each type of sorbent $(n=5)$ (Fig. 5). Alumina-N recoveries were significantly lower than the 2 other sorbents. For these cartridges,

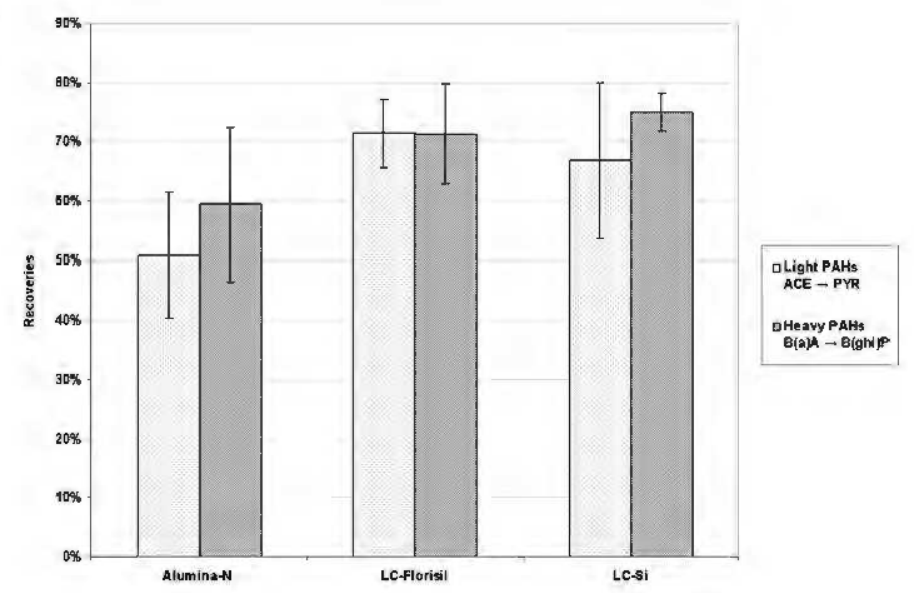

Fir 5. Light and heavy PAH recoveries obtained under the optimal PLE conditions as a function of the SPE sorbents used for post-extraction cleanup. The error bars represent the standard deviation obtained by repeating the extraction/cleanup/analysis procedure flve times with each type of cartridge.
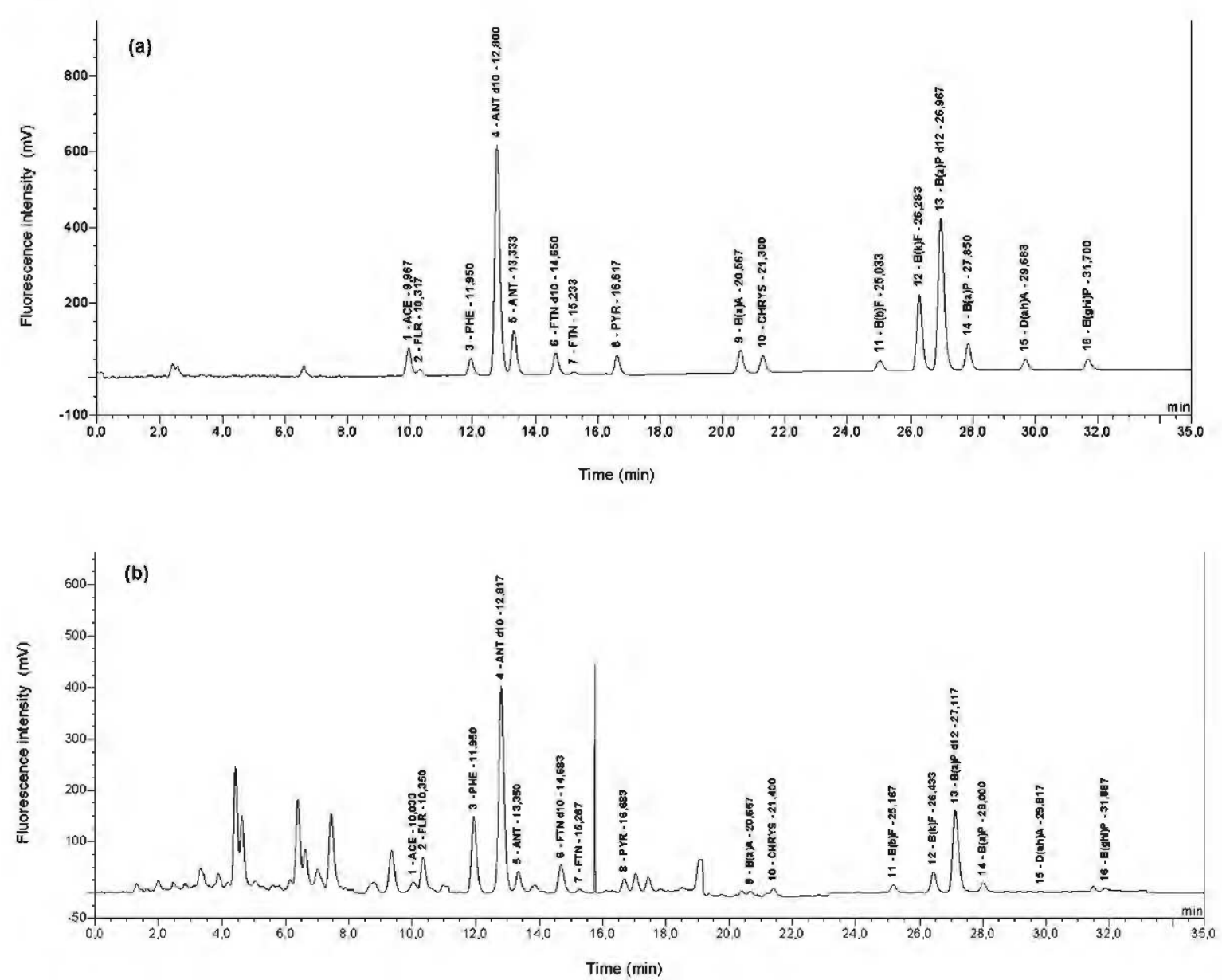

Fig. 6. HPLC chromatograms obtained by fluorescence detection (emission) after injection of: (a) a standard solution of PAHs at 10 ng L $^{-1}$ in HPLC-grade acetonitrile (prepared with Mix 16 HAP, LGC Standards, France). (b) An extract of Hypnum cupressiforme moss sampled in 2010 in the Bertiz Nature Reserve, obtained with the optimal PIE method followed by cleanup using Florisil ${ }^{\circ}$ SPE cartridges. See text and Table 2 for chromatographic experimental conditions. 
average recoveries of $51 \%$ and $59 \%$ were observed for light and heavy PAHs respectively, compared to $71 \%$ for both fractions with LC-Florisil and 67\% and 75\% for light and heavy PAHs respectively with LC-Si cartridges. LC-Florisil and LC-Si cartridges gave equivalent cleanup PAH recoveries. However, light PAH recoveries were much more variable with LC-Si than with LC-Florisil cartridges (RSD of $20 \%$ compared to $8 \%$ ). Therefore, LC-Florisil cartridges appeared to be the most appropriate for moss extract cleanup after PLE extraction, as they were the only type of SPE tested that ensured recoveries higher than $60 \%$ for all PAHs. These cartridges also appeared to give the extracts with the least coextracts.

As cleanup of moss extracts with Florisil ${ }^{\oplus}$ ensured the highest PAH selectivity and recoveries, Supelclean LC-Florisil $(1 \mathrm{~g} / 6 \mathrm{~mL})$ cartridges were chosen and used in subsequent experiments. Fig. 6 shows a chromatogram obtained with the optimal analytical procedure combining optimal PLE conditions $\left(80^{\circ} \mathrm{C}, 2 \mathrm{~min} \times 5 \mathrm{~min}\right)$ and Florisil ${ }^{\$}$ cleanup. The chromatogram of a standard solution is also included to show the low interfering compound content in the moss extract chromatogram.

\subsection{Validation of the analytical procedure}

The accuracy of the optimal analytical procedure was verified by applying PLE extraction three times, under the optimal conditions $\left(2 \mathrm{~min} \times 5 \mathrm{~min}\right.$ at $80^{\circ} \mathrm{C}$ ) followed by cleanup with Supelclean LCFlorisil (1 g/6 mL) cartridges, to a reference material (IAEA-140-OC Fucus ( $35 \mathrm{~g}$ ) from $A N A L A B$ ) containing the 13 target PAHs.

The International Atomic Energy Agency (IAEA) supply reference material with recommended values for 9 target PAHs (ANT, PHE, FTN, PYR, B(a)A, CHR, B(k)F, B(a)P, B(ghi)P), established on the basis of 8-28 statistically valid results submitted during an international laboratory inter-comparison exercise [43]. As shown in Fig. 7, concentrations of 8 target PAHs measured (ANT, PHE, FTN, PYR, CHR, B(k)F, B(a)P, B(ghi)P) were included in the recommended value ranges (95\% confidence intervals). Only B(a)A was slightly overestimated, due to the presence of chromatographic interfering peaks, because the reference material contains numerous other organic compounds such as polychlorinated biphenyls (PCBs) and organochlorine pesticides (OCPs).

The IAEA also supply information values for ACE, FLR, B(b)F and D(ah)A (established with 3-7 accepted laboratory results). The concentrations measured with optimal PLE and SPE conditions were within the information value $95 \%$ confidence intervals.

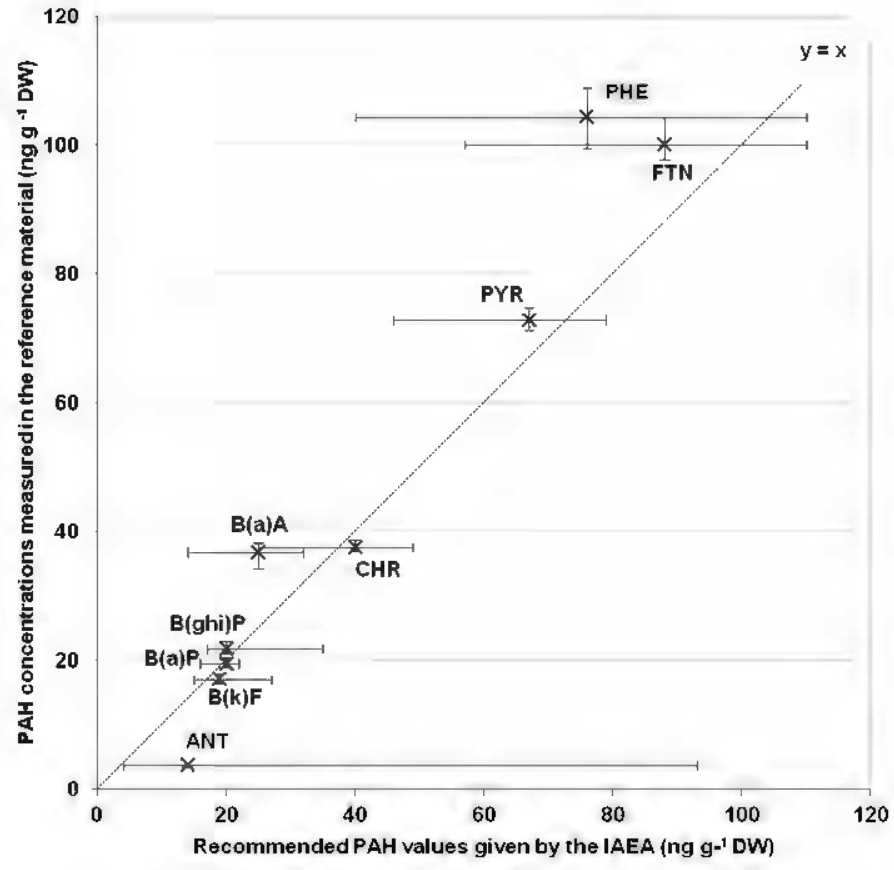

Fig. 7. Concentrations of 9 target PAHs measured in the reference material IAEA$140 / 0 \mathrm{C}$ Fucus $(35 \mathrm{~g}$ ) (ANALAB, France) as a function of the recommended values (ng g ${ }^{-1}$, based on dry weight DW). The analytical procedure was performed on 3 replicates of reference material. The experimental levels are represented by the mean concentration, and the error bars correspond to the concentration range measured (minimum and maximum). The recommended values are represented by the mean value given by the IAEA, and the error bars correspond to the $95 \%$ confidence intervals (based on 8-28 results depending on compound). The dotted line $(y=x)$ represents the case where the experimental value is equal to the recommended value.

\subsection{Study of spatial and inter-species variability at a rural site}

Using the optimal analytical procedure, the 13 target PAHs were quantified in the moss samples collected from the remote site in the Aralar Range located in Navarra, Spain (Table 5). Average total concentrations of $133 \pm 5$ and $130 \pm 5 \mathrm{ng} \mathrm{g}^{-1}$ (dry weight) were measured in the $H$. splendens (Hedw.) Schimp. and H. cupressiforme Hedw. samples, respectively. The levels were of the same order of magnitude as those measured in the $H$. splendens and $H$. cupressiforme mosses sampled over the past years in rural areas of European countries [4,27,32]. A previous study carried out in 2008

Table 5

Mean and median individual and total concentrations ( $\mathrm{ng}^{-1}$ dry weight) and corresponding standard deviations (SD) of 13 PAHs in two species of moss (Hylocomium splendens (Hedw.) Schimp. and Hypmum cupressiforme Hedw.) sampled at a remote site in the Aralar Range (Navarra, Spain). The results were obtained by applying the optimal extraction/cleanup/analysis procedure to 9 samples of Hylocomium splendens and 3 samples of Hypnum cupressiforme.

\begin{tabular}{|c|c|c|c|c|c|c|}
\hline \multirow[t]{3}{*}{ PAHS } & \multicolumn{3}{|c|}{ Concentrations (ng ${ }^{-1}$ DW) } & \multicolumn{3}{|c|}{ Concentrations (ngg ${ }^{-1}$ DW) } \\
\hline & \multicolumn{3}{|c|}{ Hylocominum splendens (Hedw.) Schimp. } & \multicolumn{3}{|c|}{ Hypnum cupressiforme Hedw. } \\
\hline & Mean & Median & SD & Mean & Median & SD \\
\hline Acenaphthene (ACE) & 3.5 & 3.1 & 0.4 & 2.9 & 2.9 & 0.2 \\
\hline Fluorene (FLR) & 30.3 & 30.1 & 2.8 & 240 & 24.0 & 3.3 \\
\hline Phenanthrene (PHE) & 19.2 & 19.8 & 1.3 & 19.0 & 17.9 & 1.9 \\
\hline Anthracene (ANT) & 1.3 & 1.1 & 0.2 & 1.2 & 1.2 & 0.1 \\
\hline Fluoranthene (FTN) & 15.5 & 15.5 & 0.8 & 15.7 & 15.5 & 0.5 \\
\hline Pyrene (PYR) & 26.3 & 25.8 & 4.0 & 31.9 & 32.6 & 2.3 \\
\hline Benz(a)anthracene (B(a)A) & 4.4 & 4.1 & 0.7 & 2.8 & 2.6 & 0.3 \\
\hline Chrysene (CHR) & 8.2 & 7.9 & 0.9 & 7.6 & 8.3 & 1.3 \\
\hline Benzo(b)fluoranthene (B(b)F) & 8.5 & 8.2 & 0.8 & 7.2 & 7.1 & 0.7 \\
\hline Benzo(k)fluoranthene $(\mathrm{B}(\mathrm{k}) \mathrm{F})$ & 3.5 & 3.5 & 0.4 & 3.0 & 3.0 & 0.2 \\
\hline Benzo(a)pyrene $(B(a) P)$ & 5.2 & 5.0 & 0.5 & 4.0 & 4.1 & 0.3 \\
\hline Dibenz(a,h)anthracene (D(ah)A) & 1.6 & 1.5 & 0.3 & 12 & 1.2 & 0.1 \\
\hline Benzo(g,h,i)perylene (B(ghi)P) & 5.8 & 5.5 & 0.6 & 4.4 & 4.5 & 0.7 \\
\hline Total & 133.3 & 131.2 & 4.8 & 130.0 & 125.0 & 4.7 \\
\hline
\end{tabular}


in the Bertiz Nature Reserve, located $35 \mathrm{~km}$ from the Aralar Range sampling site, also showed average total levels for the 13 PAHs of approximately $100 \mathrm{ngg}^{-1}$ (dry weight) in the moss $H$. cupressiforme [29].

Average individual concentrations ranged from $1.3 \pm 0.2$ to $30 \pm 3 \mathrm{ng} \mathrm{g}^{-1}$ (dry weight) for ANT and FLR respectively in $\mathrm{H}$. splendens and from $1.2 \pm 0.1$ to $32 \pm 3 \mathrm{ngg}^{-1}$ (dry weight) for ANT and PYR respectively in $H$. cupressiforme. The major compounds in both species were FLR, PHE, FTN and PYR, with concentrations over $10 \mathrm{ngg}^{-1}$ (dry weight), as previously found in the Bertiz Nature Reserve [29].

The nine samples of $H$. splendens were sampled from soil at several points over $200 \mathrm{~m}$, at the limit between grassland and forest, where local conditions varied slightly (light intensity, throughfall precipitation...) in function of the canopy cover. The analysis of these samples revealed relative standard deviations lower than $20 \%$ for all target PAHs, of the same order as the reproducibility previously determined in this study with a homogenous composite sample. The low variability showed that the local environmental conditions had a negligible influence on bioaccumulation of PAHs by the mosses.

Individual concentrations of $F L R, B(a) A, B(b) F, B(k) F, B(a) P$, $\mathrm{D}(\mathrm{ah}) \mathrm{A}, \mathrm{B}(\mathrm{ghi}) \mathrm{P}$ were significantly lower in $\mathrm{H}$. cupressiforme than in $H$. splendens samples. PYR concentrations were significantly higher in $\mathrm{H}$. cupressiforme. The quantity of PAHs bioaccumulated was therefore specific to the moss species, as shown previously by Galuszka [32] who observed higher PAH accumulation in $H$. splendens than in Pleurozium schreberi mosses. The variability of bioaccumulation between species can be explained by their different morphologies and/or their growth conditions. $H$. splendens is a weft moss with feathery fronds, whereas $H$. cupressiforme has prostrate, creeping stems which form smooth, dense mats [51]. Moreover, $H$. cupressiforme was growing on tree stumps and dead branches under forest cover, whereas $H$. splendens was collected from soil at the limit between the forest and grassland. Therefore, to biomonitor atmospheric deposition of PAHs with several moss species, preliminary inter-species calibration is necessary.

\section{Conclusions}

PAH extraction from the moss $I$. myosuroides Brid., using Soxtec with $n$-hexane showed average $\mathrm{PAH}$ recoveries of $67-77 \%$ and concentrations of approximately $200 \mathrm{ng} \mathrm{g}^{-1}$ (dry weight). To increase the extraction turnover and reduce solvent consumption, PLE was tested. The PLE factorial design revealed the optimal extraction conditions: $80^{\circ} \mathrm{C}$ for 2 cycles of $5 \mathrm{~min}$, giving maximum recoveries and ensuring good selectivity for moss PAH determination at trace levels. Under optimal PLE conditions, satisfactory average recoveries of $68-70 \%$ were obtained and concentrations similar to those for the Soxtec extraction procedure were measured, whereas solvent volume was divided by 3 and total extraction time by 5 . Several normal phase SPE cleanup steps were tested. Supelclean LC-Florisil $(1 \mathrm{~g} / 6 \mathrm{~mL})$ cartridges appeared to be the most efficient since the purified extracts contained the least interfering compounds and the highest PAH concentrations. The accuracy of the optimal analytical procedure, combining the optimal PLE conditions with cleanup by Florisil ${ }^{\circledR}$ SPE, was verified on a reference material.

Finally, the optimal analytical procedure was applied to samples of $H$. splendens (Hedw.) Schimp. and $H$. cupressiforme Hedw. collected at a remote site in Navarra (Spain) in June 2010. The target PAHs were quantifiable and showed similar levels to those of previous studies carried out in Europe and locally in Navarra. The study revealed negligible on-site spatial variability for the PAH levels in the $H$. splendens samples, but significant differences between the levels in the two species, due to their morphology and growth conditions.

\section{Acknowledgments}

This work was supported by the Communautê de Travail des Pyrénées/Communidad de Trabajo de los Pirineos (CTP). We wish to thank Alicia Ederra from the Departamento de Biología Vegetal of the University of Navarra (Pamplona, Spain) for helping us with her botanical knowledge during the moss species identification phase, and Nerea Aragonés, Raúl Bermejo, Laura González, José Miguel Otano and Jesús Miguel Santamaría of the Laboratorio Integrado de Calidad Ambiental (LICA) of the University of Navarra (Pamplona, Spain) for supplying us with moss samples. We also wish to thank Laure Candy and Christine Raynaud from the Laboratoire de Chimie Agro-Industrielle (LCA) for their advice on experimental designs.

\section{References}

[1] A. Björseth, T. Ramdahl, Sources and Emissions of PAH, Marcel Dekker, New York, 1985.

[2] L.H. Lim, R.M. Harrison, S. Harrad, Environ. Sci. Technol. 33 (1999) 3538.

[3] A.M. Mastral, M.S. Callến, R. Murillo, T. Garcia, Environ. Sci. Technol. 33 (1999) 4155.

[4] I. Holoubek J. Klanova, J. Jarkovsky, J Kohoutek, J Environ Monit 9(2007) 557.

[5] K.M. Nauss, Diesel Exhaust: A Critical Analysis of Emissions, Exposure and Health Effects, Health Effects Institute (HEI) Special Report, Health Effects Institute, Diesel Working Group, Cambridge, 1995, p. 6.

[6] S. Dejean, C. Raynaud, M. Meybeck, J.-P. Della Massa, V. Simon, Environ. Monit. Assess. 148 (2009) 27.

[7] A. Motelay-Massei, D. Ollivon, B. Garban, K. Tiphagne-Larcher, I. Zimmerlin, M. Chevreuil, Chemosphere 67 (2007) 312.

[8] J.P. Garrec, C. Van Haluwyn, Biosurveillance végétale de la qualité de l'air Concepts, méthodes et applications (Air Quality Biomonitoring with Plants Concepts, Methods and Applications), Lavoisier, Paris, 2002

[9] A. Klumpp, W. Ansel, G. Klumpp, J. Breuer, P. Vergne, M.J. Sanz, S. Rasmussen, H. Ro-Poulsen, A. Ribas Artola, J. Peñuelas, et al., Atmos. Environ. 43 (2009) 329

[10] Y.Q. Wang, S. Tao, X.C. Jiao, R.M. Coveney, S.P. Wu, B.S. Xing, Environ. Pollut. $151(2008) 158$.

[11] F. De Nicola, L. Claudia, P. MariaVittoria, M. Giulia, A. Anna, Atmos. Environ. 45 (2011) 1428

[12] N. Ratola, J.M. Amigo, M.S.N. Oliveira, R. Araújo, J.A. Silva, A. Alves, Environ. Exp. Bot. 72 (2011) 339.

[13] S. Orecchio, A. Gianguzza, L. Culotta, Environ. Res. 107 (2008) 371

[14] M. Blasco, C. Domeno, P. Lopez, C. Nerin. J. Environ. Monit. 13 (2011) 2588.

[15] Z.M. Migaszewski, A. Galuszka, P. Paslawski, Environ. Int. 28 (2002) 303.

[16] S. Dolegowska, Z.M. Migaszewski, Ecotoxicol. Environ. Saf. 74 (2011) 1636.

[17] H. Harmens, D.A. Norris, E. Steinnes, E. Kubin, J. Piispanen, R. Alber, Y. Aleksiayenak, O. Blum, M. Coskun, M. Dam, et al., Environ. Pollut. 158 (2010) 3144.

[18] M. Krmar, D. Radnovic, D.T. Mihailovic, B. Lalic, J. Slivka, I. Bikit, Appl. Radiat. Isot. 67 (2009) 1139.

[19] H. Harmens, D.A. Norris, D.M. Cooper, G. Mills, E. Steinnes, E. Kubin, L. Thöni, J.R. Aboal, R. Alber, A. Carballeira, et al., Environ. Pollut. 159 (2011) 2852

[20] X.-Y. Liu, H.-Y. Xiao, C.-Q Liu, Y.-Y. Li, H.-W. Xiao, Y.-L. Wang, Environ. Pollut $158(2010) 2273$.

[21] H.-Y.Xiao, C.-G. Tang, H.-W. Xiao, Y.-L. Wang, X.-Y.Liu, C.-Q. Liu, Environ. Pollut $158(2010) 1726$.

[22] F. Borghini, J.O. Grimalt, J.C. Sanchez-Hernandez, R. Bargagli, Chemosphere 58 (2005) 271.

[23] A. Carballeira, J. Ángel Fernández, J.R. Aboal, C. Real, J.A. Couto, Atmos. Environ. 40 (2006) 5776.

[24] G.T. Yogui, J.L. Sericano, Chemosphere 73 (2008) 1589

[25] R. Gerdol, L. Bragazza, R. Marchesini, A. Medici, P. Pedrini, S. Benedetti, A. Bovolenta, S. Coppi, Atmos. Environ. 36(2002) 4069.

[26] I. Holoubek, P. Korínek, Z. Seda, E. Schneiderová, I. Holoubková, A. Pacl, J. Tríska, P. Cudlín, J. Cáslavský, Environ. Pollut. 109 (2000) 283.

[27] V. Krommer, H.G.Zechmeister, I. Roder, S. Scharf, A. Hanus-Illnar, Chemosphere $67(2007) 1956$.

[28] H. Zechmeister, S. Dullinger, D. Hohenwallner, A. Riss, A. Hanus-Illnar, S. Scharf, Environ. Sci. Pollut. Res. 13 (2006) 398

[29] L. Foan, C. Sablayrolles, D. Elustondo, E. Lasheras, L. González, A. Ederra, V. Simon, J.M. Santamaría, Atmos. Environ. 44 (2010) 3207.

[30] E. Ötvös, L.O. Kozák, J. Fekete, V.K. Sharma, Z. Tuba, Sci. Total Environ. 330 (2004) 89.

[31] A. Ares, J.R. Aboal, J.A. Fernández, C. Real, A. Carballeira, Atmos. Environ. 43 (2009) 5501.

[32] A. Galuszka, Chemosphere 67 (2007) 1415

[33] X. Liu, G. Zhang, K.C. Jones, X. Li, X. Peng, S. Qi, Atmos. Environ. 39 (2005) 5490.

[34] K.-D. Wenzel, A. Hubert, M. Manz, L. Weissflog, W. Engewald, G. Schüürmann, Anal. Chem. 70 (1998) 4827 
[35] M. Tobiszewski, A. Mechlinska, B. Zygmunt, J. Namniesnik, Trends Anal. Chem. 28 (2009) 943

[36] E. Björklund, T. Nilsson, S. Bowadt, Trends Anal. Chem. 19 (2000) 434

[37] DIONEX, Methods Optimization in Accelerated Solvent Extraction (ASE) Dionex Corporation Technical Note 208, LPN 0982-02 PDF 9/04, 2004 (cited 2012 January 16th). Available from: http://www.dionex.com/enus/webdocs/4736-TN208.pdf.

[38] H. Giergielewicz-Mozajska, L. Dabrowski, J. Namiesnik, Crit. Rev. Anal. Chem. 31 (2001) 149.

[39] M. Jánská, M. Tomaniová, J. Hajslová, V. Kocourek, Anal. Chim. Acta 520 (2004) 93.

[40] N. Ratola, S. Lacorte, A. Alves, D. Barceló, J. Chromatogr. A 1114 (2006) 198.

[41] P. Konieczka, L. Wolska, J. Namiesnik, Trends Anal. Chem. 29 (2010) 706.

[42] M. Blasco, C. Domeño, C. Nerín, Environ. Sci. Technol. 40 (2006) 6384.

[43] J.P. Villeneuve, C. Cattini, F.P. Carvalho, World-wide and Regional Intercomparison for the Determination of Organochlorine Compounds and Petroleum
Hydrocarbons in Fucus Sample IAEA-140, International Atomic Energy Agency, Marine Environment Laboratory, Monaco, 1997 (cited 2012 January 16th). Available from: http://nucleus.iaea.org/rpst/Documents/al_140.pdf.

[44] B. Markert, Sci. Total Environ. 176 (1995) 45.

[45] P. Quevauviller, Sci. Total Environ. 176 (1995) 141.

[46] E. Björklund, S. Sporring, K. Wiberg, P. Haglund, C.v. Holst, Trends Anal. Chem. 25 (2006) 318

47] N. Saim, J.R. Dean, M.P. Abdullah, Z. Zakaria, Anal. Chem. 70 (1998) 420.

[48] M. Blasco, C. Domeño, K. Bentayeb, C. Nerín, Int. J. Environ. Anal. Chem. 87 (2007) 833.

[49] J.Tranchant, Manuel pratique de chromatographie en phase gazeuse (Practical Handbook of Gas Chromatography), Masson, France, Paris, 1995.

[50] P. Konieczka, J. Namiesnik, J. Chromatogr. A 1217 (2010) 882.

[51] B. Goffinet, A.J. Shaw, Bryophyte Biology, second ed., Cambridge University Press, Cambridge, 2009. 